\title{
INFLUENCE OF METAKAOLIN ON PROPERTIES OF CONCRETE MODIFIED WITH POLYCARBOXYLATE ADMIXTURE FOR RIGID PAVEMENT REPAIR
}

\author{
${ }^{1}$ Kryzhanovskiy V.O., Engineer, \\ vitolloscience@gmail.com, ORCID: 0000-0003-1332-1922 \\ ${ }^{1}$ Kroviakov S.O., Doctor of Engineering, Assistant Professor, \\ skrovyakov@ukr.net, ORCID 0000-0002-0800-0123 \\ ${ }^{1}$ Zavoloka M.V., PhD, Professor, \\ mvzavoloka@ukr.net, ORCID: 0000-0002-2080-1230 \\ ${ }^{1}$ Odessa State Academy of Civil Engineering and Architecture \\ 4, Didrichson street, Odessa, 65029, Ukraine
}

\begin{abstract}
The effect of partial cement replacement with high-activity metakaolin on the strength, frost resistance, shrinkage and abrasion resistance of concrete modified with polycarboxylate admixture MasterGlenium SKY 608. Portland cement CEM II/A-S 42.5 (ПЦ II/AШ-500) with partial metakaolin replacement $15 \mathrm{~kg}(3.75 \%)$ and $30 \mathrm{~kg}(7.5 \%)$ was used for concrete preparation. The amount of superplasticizer in all studied compositions was $1.2 \%$ of cement weight. Slump of concrete mixtures was $6 \ldots 7 \mathrm{~cm}$.

It was found that with increasing amount of metakaolin W/C ratio of mixtures increased slightly. The early compressive and flexural strength (at the age of 2 days) of the composition without metakaolin was higher than similar indicators with partial cement replacement with the active mineral admixture. It is worth noting the positive effect of increasing the metakaolin amount on early strength, because the composition with $30 \mathrm{~kg}$ metakaolin had strengths higher at 2 days of in difference to the composition with $15 \mathrm{~kg}$ metakaolin.

It is necessary to note high frost resistance of all obtained concretes. Its grade of frost resistance reached F200 (evaluated according to the method for road concrete), which is equivalent to the grade F600 for structural concrete. Abrasion resistance was in the low range $\left(0.30-0.31 \mathrm{~g} / \mathrm{cm}^{2}\right)$, total shrinkage does not exceed $0.28 \mathrm{~mm} / \mathrm{m}$, which in combination with high frost resistance has a positive effect on the durability of concrete mixtures for rigid pavements repair.
\end{abstract}

Keywords: rigid pavement, repair, early strength, shrinkage, frost resistance, abrasion resistance, metakaolin, superplasticizer.

Introduction. Concrete technology is constantly evolving. Today classic three-component concretes are practically not used. Concrete mixtures modification takes place using superplasticizers and active mineral admixtures, one of which is metakaolin [1-7]. Environmental pollution is acute issue in cement production [8]. It led to the use of pozzolanic products, including metakaolin, as a partial replacement for clinker.

Metakaolin is a heating product of purified kaolinite clay at a temperature of $600-900^{\circ} \mathrm{C}$. When $\mathrm{Al}_{2} \mathrm{O}_{3} \cdot 2 \mathrm{SiO}_{2} \cdot \mathrm{H}_{2} \mathrm{O}$ (kaolin) is heating the crystal structure is deformed due to the evaporation of bound water. The result is a non-hydrated reactive form consisting of an amorphous aluminosilicate - metakaolin.

The investigation introduces results of a complex concrete mixture modification with the polycarboxylate admixture BASF MasterGlenium SKY 608 and high-activity metakaolin.

Analysis of recent researches and problem statement. The characteristics of concrete are determined by its strength and properties that determine its durability under typical operating conditions. With the advent of various types superplasticizers and a more complete exposure of the high-activity metakaolin reactivity, it became feasible to obtain high performance concretes $[3,9,10]$, with high early strength (minimum $30 \mathrm{MPa}$ on the $2^{\text {nd }}$ day) and grade strength (minimum $60 \mathrm{MPa}$ ). High frost resistance (minimum F200 for pavement concretes and F600 for structural concretes) and low abrasive resistance (no more $0.4 \mathrm{~g} / \mathrm{cm}^{2}$ ) ensure high durability of the material. The lifetime of

Bulletin of Odessa State Academy of Civil Engineering and Architecture, 2021, no. 82, page 90-97 
structures made of such concrete reaches 200 years. This allows them to be used as a repair material for rigid pavements repair.

Ukraine occupies one of the leading places in the world of industrial kaolin reserves, their volume exceeds 300 million tons [11]. Metakaolin was first used as a pozzolanic admixture for concrete mixtures in Brazil (1962) for the dams' construction [12]. In addition, the metakaolin manufacture, in comparison with Portland cement, requires a much lower calcination temperature, as a result, less $\mathrm{CO}_{2}$ emissions. According to $[3,6]$ for each ton of cement produced, $0.82-1$ ton of $\mathrm{CO}_{2}$ is emmited.

Depending on the type and cement dosage used in the concrete, the optimal amount of its replacement with metakaolin is up to $20 \%$ [2-7, 11-14]. The pozzolanic properties of metakaolin improve the physical and mechanical properties of concrete due to the formation of additional calcium hydrosilicate $(\mathrm{C}-\mathrm{H}-\mathrm{S})$ as a result of the interaction of cement hydration products $\left(\mathrm{Ca}(\mathrm{OH})_{2}\right)$ with a mineral filler, which has a smaller specific surface area in contrast to cement. It should be noted that the $\mathrm{W} / \mathrm{C}$ of concrete mixtures with metakaolin increases with raise in its amount. It is necessary to use water-reducing admixtures-superplasticizers to restore the mixture workability at a lower W/C.

Research objective is to study the effect of cement replacing with high-activity metakaolin on early and grade strength, frost resistance, wear resistance and shrinkage of concrete modified with BASF additive MasterGlenium SKY 608.

Materials and research methods. The following source materials were used in research. Portland cement ПЦ II/A-Ш-500 (CEM II/A-S 42.5), manufactured by PJSC "Dyckerhoff Cement Ukraine". Metakaolin obtained by heat treatment of enriched natural kaolin from the Dermankovskoye field of the Rivne region, manufactured by Ltd "Western Kaolin Company". Granite crushed stone of the Gorikhovsky quarry with nominal maximum size $20 \mathrm{~mm}$ and quartz sand of the Nikitovsky quarry (Voznesensky district) were used as aggregates. Sieve analysis of aggregates is presented in Fig. 1. Modifying admixture MasterGlenium SKY 608 based on polycarboxylate ether was used in an amount of $1.2 \%$ by weight of cement. This dosage has been selected based on past research [15]. The cement replacement with metakaolin was 15 and $30 \mathrm{~kg} / \mathrm{m}^{3}$ (3.75\% and $7.5 \%$ of the cement mass). The concrete mix preparation process and sample testing were carried out in accordance with current requirements.

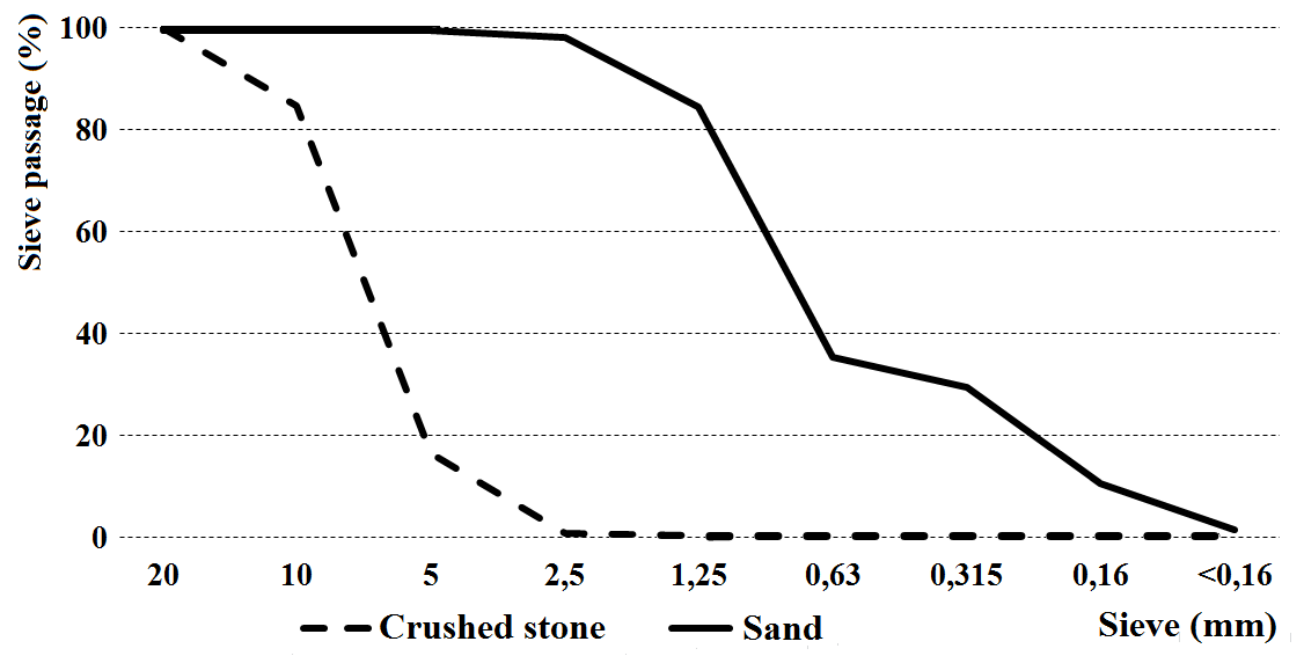

Fig. 1. Coarse and fine aggregates gradation

Research results. 3 batches of concrete samples were fabricated (in each batch 18 cubes $10 \times 10 \times 10 \mathrm{~cm}$ and 8 beams $40 \times 10 \times 10 \mathrm{~cm})$. The compositions of the investigated concretes and $\mathrm{W} / \mathrm{C}$ are shown in Table 1 . Slump of concrete mixtures was $(6 \ldots 7 \mathrm{~cm})$, which meets the workability requirements for rigid pavement repair concrete mixtures. 
Table 1 - Concrete mixtures and W/C

\begin{tabular}{|c|c|c|c|c|c|c|c|}
\hline № & $\begin{array}{l}\text { Cement, } \\
\mathrm{kg} / \mathrm{m}^{3}\end{array}$ & $\begin{array}{c}\text { Crushed } \\
\text { stone, } \\
\mathrm{kg} / \mathrm{m}^{3}\end{array}$ & $\begin{array}{l}\text { Sand, } \\
\mathrm{kg} / \mathrm{m}^{3}\end{array}$ & $\begin{array}{c}\text { Metakaolin, } \\
\mathrm{kg} / \mathrm{m}^{3}\end{array}$ & $\begin{array}{c}\text { Admixture } \\
\text { MasterGlenium } \\
\text { SKY 608, \% }\end{array}$ & $\begin{array}{l}\text { Water, } \\
1 / \mathrm{m}^{3}\end{array}$ & $\mathrm{~W} / \mathrm{C}$ \\
\hline 1 & 400 & \multirow{3}{*}{1195} & 830 & 0 & \multirow{3}{*}{1.2} & 115 & 0.288 \\
\hline 2 & 385 & & 825 & 15 & & 124 & 0.322 \\
\hline 3 & 370 & & 820 & 30 & & 126 & 0.341 \\
\hline
\end{tabular}

The average density of the investigated concretes ranged from 2480 to $2580 \mathrm{~kg} / \mathrm{m}^{3}$. Compression and flexural strength tests were carried out for each batch at the age 2 and 28 days. The obtained data are shown in Fig. 2, 3.

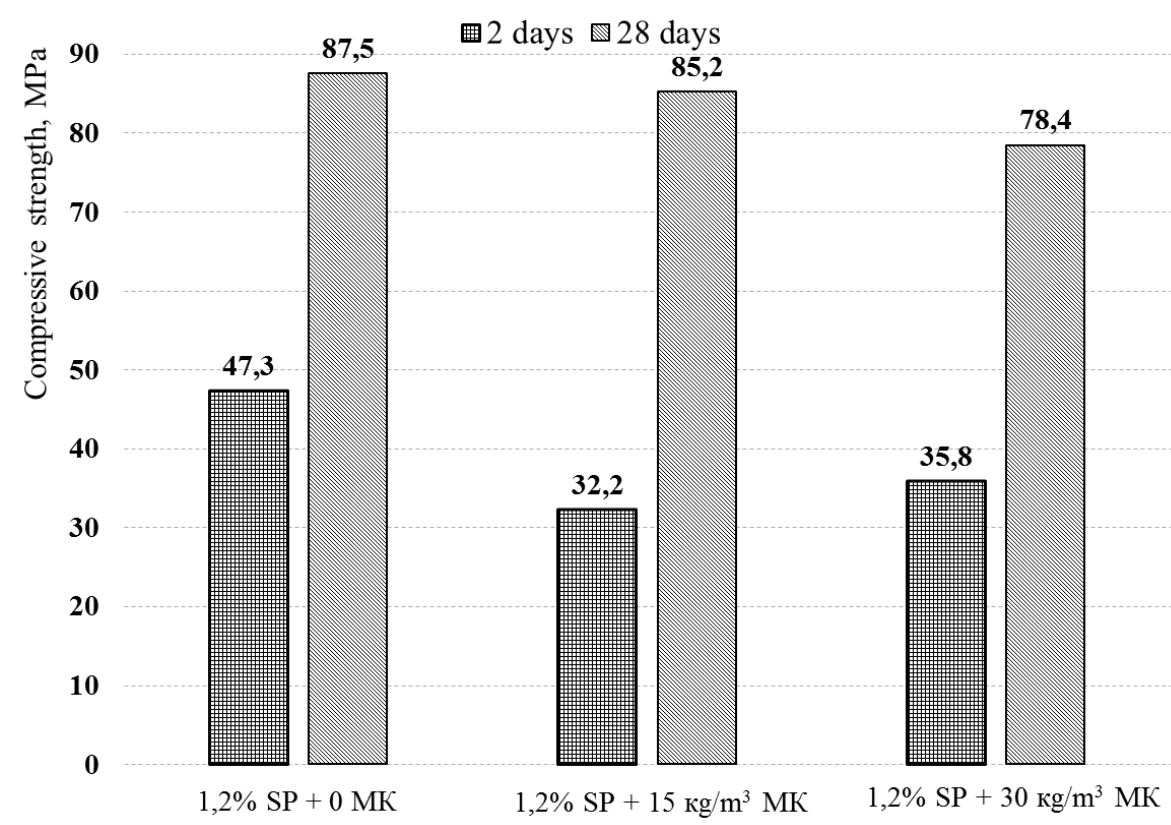

Fig. 2. Compressive strength of the investigated concretes at the age of 2, 28 days
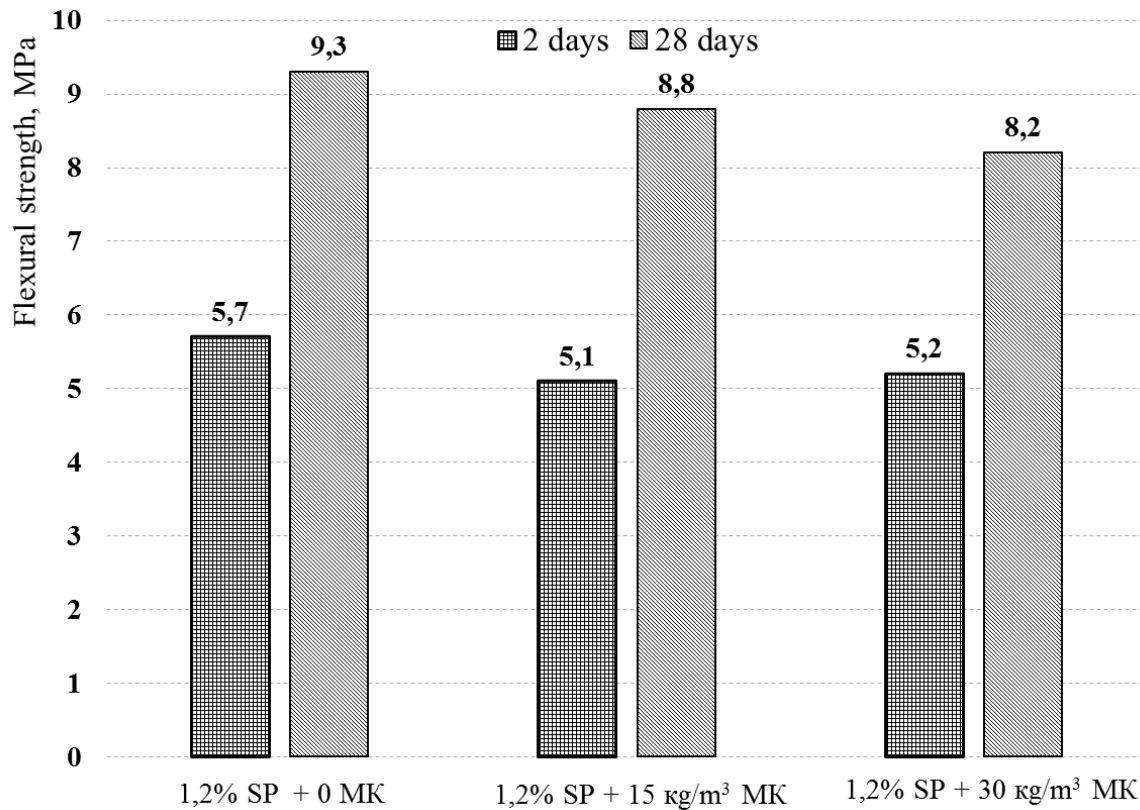

Fig. 3. Flexural strength of the investigated concretes at the age of 2, 28 days 
Data analysis in Fig. 2, 3 show that the early and grade compressive and flexural strength of modified concrete without metakaolin addition $\left(\mathrm{f}_{\text {ck. } \text { cube. } 2}=47.3 \mathrm{MPa}, \mathrm{f}_{\text {ck. } \text { cube } .28}=87.5 \mathrm{MPa}, \mathrm{f}_{\text {c.tf. } 2}=\right.$ $5.7 \mathrm{MPa}, \mathrm{f}_{\text {c.tf. } 28}=9.3 \mathrm{MPa}$ ) is slightly higher than similar strength indicators of concrete with partial cement replacement with metakaolin. This is caused by the water demand increase of concrete mixtures due to the greater dispersion of metakaolin relative to cement. It should be noted that the compressive and flexural of composition № 3 at $2^{\text {nd }}$ day age (30 kg metakaolin) with a higher W/C was $5.9 \%$ higher than the strength of composition № 2 (15 kg metakaolin). This is due to increase in the amount of $(\mathrm{C}-\mathrm{H}-\mathrm{S})$ in the early ages [11] with an increase of the metakaolin conctent. Probably, this trend can persist with a further increase of the metakaolin content. In this case, the increase of the mixture W/C must be compensated by adjusting of the superplasticizer amount.

On the basis of Portland cement ПЦ II/A-Ш-500 (CEM II/A-S 42.5) with an amount of BASF MasterGlenium SKY 608 additive 1.2\% of its mass, high-performance concrete with compressive strength $87.5 \mathrm{MPa}$ was obtained, which approximately corresponds to the grade C50/60. $15 \mathrm{~kg}$ replacement of cement with metakaolin made it possible to obtain concrete of the same grade C50/60 with strength $85.2 \mathrm{MPa}$, and after $30 \mathrm{~kg}$ cement replacement, concrete grade C45/55 with strength 78.4 MPa was obtained.

Early strength is an important parameter of the concrete quality for the rigid pavement repair. Compressive strength of the investigated modified concretes at $2^{\text {nd }}$ day age was $54 \%, 38 \%$ and $46 \%$ of the grade for compositions 1, 2 and 3, respectively. Flexural strength at 2nd day age for these compositions was $61 \%, 58 \%$ and $63 \%$ of the strength at $28^{\text {th }}$ day. Strength features of the obtained concretes allow them to be used as a repair material since main indicator of the mechanical properties for pavements is the early flexural strength, which was more than $5 \mathrm{MPa}$ on the $2^{\text {nd }}$ day of hardening for all researched compositions.

Frost resistance of the concretes was determined according to the Ukrainian building state code DSTU B V.2.7-49-96, 3rd accelerated method. The obtained values for all compositions corresponded to the frost resistance of the F200 grade for road concretes, which is equivalent to the F600 grade for structural concretes. High frost resistance of the compositions with metakaolin is explained by the fact that with an increase in its amount, a greater number of new formations (C-H-S) are formed $[4,14,16-20]$ that reduce the average pore size.

Abrasion resistance for road concrete is an important and integral characteristic of its durability. The most important factors affecting on the wear resistance of concrete are its strength, the nature and amount of aggregate, defined as the cement/aggregate ratio, and its maximum size [21-23]. Tests were carried out according to DSTU B V.2.7-212:2009. The results showed high abrasion resistance of all investigated concretes $-0.30 \ldots 0.31 \mathrm{~g} / \mathrm{cm}^{2}$, which ensures their durability under the influence of road transport.

For rigid pavement repair compositions, an important indicator of the quality of concrete is its shrinkage, which largely determines the joint work of new and old concrete. Deformations of fresh concrete can be caused due to the following reasons [24-27]: plastic shrinkage, chemical shrinkage, which is an integral part of autogenous shrinkage and may not be considered in practice, drying shrinkage, carbonation shrinkage develops over a long period of time and constitutes an insignificant value that can be neglected. Additional factors causing shrinkage deformations can be stresses caused by unacceptable temperature fluctuations in massive structures and the highly reactive ability of mineral additives with cement alkalis. Drying shrinkage is at least studied. It causes the main shrinkage deformations of the cement stone and depends on the type and cement content, its specific surface area and W/C ratio, which determines moisture content of the cement stone. According to researches $[25,28]$ increasing metakaolin content reduces shrinkage over time with the same W/C mixtures and equal workability.

In our study, we measured the total shrinkage, consisting of autogenous and drying shrinkage for mixtures with different W/C. Measurement of shrinkage deformations was carried out on prisms of $40 \times 10 \times 10 \mathrm{~cm}$ according to DSTU B V.2.7-216:2009. Measurements started 24 hours after concrete forming, directly after sample stripping. The measurements were carried out using a dial indicator with a graduation of $0.01 \mathrm{~mm}$ after 3 hours, 6 hours, 1, 2, 3 and 7 days. The results are shown in Fig. 4.

Bulletin of Odessa State Academy of Civil Engineering and Architecture, 2021, no. 82, page 90-97 
Conclusions and prospects for further researches. Partial replacing of the cement with metakaolin entails the need to increase W/C ratio of the concrete mixture. However, this does not significantly affect the compressive and flexural strength of concretes modified with the BASF MasterGlenium SKY 608 polycarboxylate admixture. Control concrete and concrete with metakaolin in the amount of $15 \mathrm{~kg} / \mathrm{m}^{3}$ correspond to grade C50/60. $30 \mathrm{~kg}$ of cement replacing with metakaolin, concrete grade $\mathrm{C} 45 / 55$ was obtained. Total shrinkage of concrete with partial replacement of cement with metakaolin, does not exceed $0.28 \mathrm{~mm} / \mathrm{m}$, all investigated concretes had high frost resistance (F200 for road concrete, equivalent F600 for structural concrete) and low abrasion resistance $-0.30-0.31 \mathrm{~g} / \mathrm{cm}^{2}$. Such physical and mechanical properties ensure high concrete durability for rigid pavements.

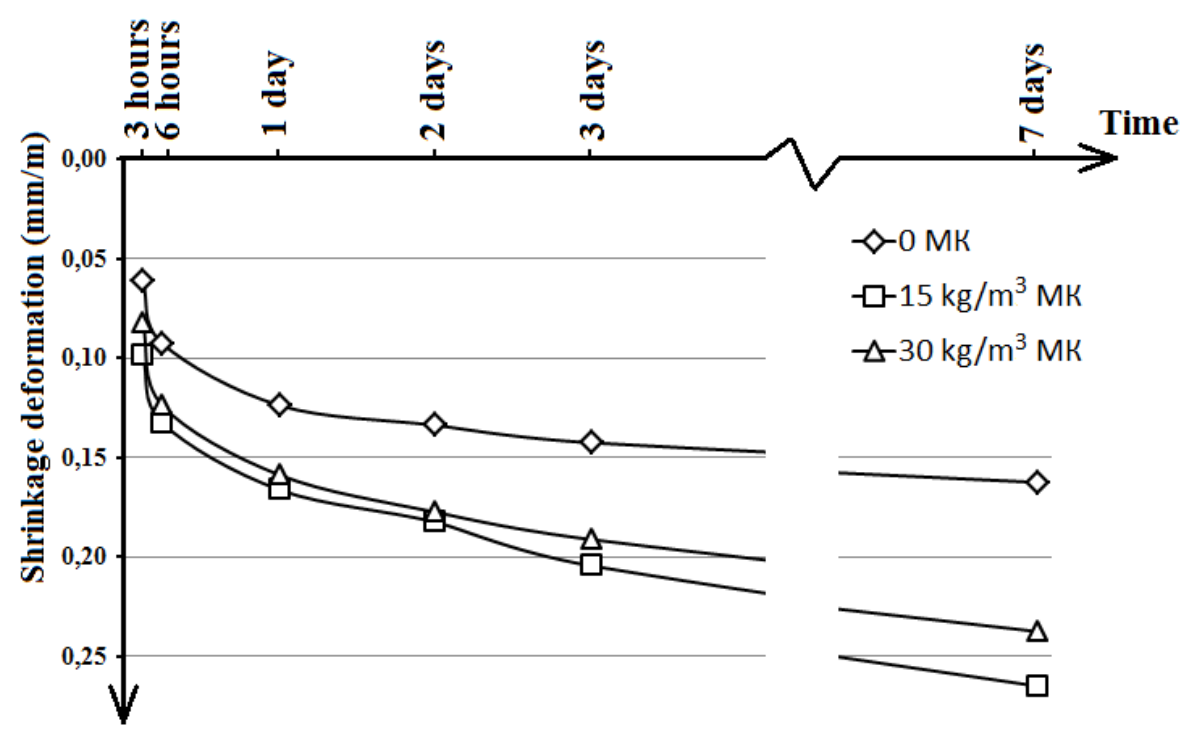

Fig. 4. Total shrinkage of investigated concretes at early ages

Further research should be directed to optimizing the dosage of various types of plasticizers, depending on the amount and cement type used in conjunction with metakaolin. It is also necessary to attend to a more detailed study of shrinkage deformations in compositions with metakaolin, since, according to [29], it is theoretically possible to reduce shrinkage by replacing cement with metakaolin and adding gypsum.

\section{References}

[1] L.I. Dvorkin, V.V. Zhitkovskyi, O.L. Dvorkin, A.R. Razumovskyi, "Metakaolin effektivnaya mineral'naya dobavka dlya betonov", Tehnologii betonov, no. 9-10, pp. 2124, 2015.

[2] N. Nithya, R. Vijaya Sarathy, B. Jose Ravindra, K.R. Keerthi Raman, "Experimental study on strength and durability properties of concrete with nano metakaolin", International Journal of Engineering and Management Research, vol. 5, Issue 2, pp. 840-843, 2015.

[3] P. Chanakya, D. Behera, "Experimental study on compressive strength of concrete by partial replacement of cement with metakaolin", International Journal of Scientific Engineering and Technology Research, vol. 5, Issue 26, pp. 5354-5358, 2016.

[4] M. Narmatha, T. Felixkala, "Metakaolin - the best material for replacement of cement in concrete", Journal of mechanical and civil engineering, vol. 13, Issue 4, pp. 66-71, 2016.

[5] M. Mohammed Ashik, D. Gomathi, "Strength properties of concrete using metakaolin", International journal of engineering research \& technology, vol. 6, Issue 11, pp. 149$152,2017$. 
[6] Matthew S. Sullivan, Mi G. Ghorzepa, Hiwa Hamid, Stephan A. Durham, S. Sonny Kim, Sustainable materials for transportation infrastructures: comparison of three commerciallyavailable metakaolin products in binary cementitious system. Infrastructures 2018.

[7] Mi Geum Chorzepa, Stephan A. Durham, Matthew Sullivan, Evaluation of Metakaolin and Slag for GDOT Concrete Specifications and Mass Concrete Provision - Phase 1. Georgia Department of Transportation, Report № FHWA-GA-17-1616, 2017.

[8] Kuruva Syamala Devi, "Impacts of cement industry on environment - an overview", Asia Pacific Journal of Reserach, vol. 1, Issue 57, pp. 156-161, 2017.

[9] Y.M. Bazhenov, V.S. Demianova, V.I. Kalashnikov, Modificirovannye vysokokachestvennye betony. Moskva: Associaciya stroitel'nyh vuzov, 2006.

[10] Sulagno Banerjee, Supratip Mondal, High strength and high performance concrete. Mauritius: LAP Lambert Academic Publishing, 2017.

[11] L.I. Dvorkin, N.V. Luschnikova, R.F. Runova, V.V. Troian, Metakaolin v budivelnykh rozchynakh i betonakh. Kiyiv: KNUBiA, 2007.

[12] E. Arunakanthi, Rao H Sudarsana, "Effects of calcium chloride in mixing and curing water on strength of high-performance metakaolin concrete", Indian journal of research, vol. 2, Issue 9, pp. 91-94, 2013.

[13] Leonid Dvorkin, Nataliya Lushnikova, Oleksandr Bezusyak, Mohammed Sonebi, Jamal Khatib, "Hydration characteristics and structure formation of cement pastes containing metakaolin", MATEC web of conferences, vol. 149, p. 8, 2018.

[14] Zenisek Michal, Vlach Tomas, Laibova Lenka, "Dosage of metakaolin in high performance concrete", Key engineering materials, vol. 722, pp. 311-315, 2016.

[15] V. Kryzhanovskyi, S. Kroviakov, "Strength of rigid pavement concretes modified with polycarboxylate admixture on different types of cement", Bulletin of Odessa State Academy of Civil Engineering and Architecture, vol. 79, pp. 92-98, 2020.

[16] Jian-Tong Ding, Zongjin Li, "Effects of metakaolin and silica fume on properties of concrete, ACI Materials Journal, 99 (4), pp. 393-398, 2002.

[17] P. Dinakar, Pradosh K. Sahoo, G. Sriram, "Effect of metakaolin concrete on the properties of high strength concrete", International journal of concrete structures and materials, vol. 7, no. 3, pp. 215-223, 2013.

[18] S.N. Patil, A.K. Gupta, S.S. Deshpande, "Metakaolin - pozzolanic material for cement in high strength concrete", IOSR International journal of mechanical and civil engineering, 2 (0), pp. 46-49, 2013.

[19] K. Srinivasu, M.L.N. Krishna Sai, Venkata Sairam Kumar N, "A review on use of metakaolin in cement mortar and concrete", IOSR International journal of innovative research in science, engineering and technology, vol. 3, Issue 7, pp. 14697-1470, 2014.

[20] M.S. Morsy, Y. Al-Salloum, T. Almusallam, H. Abbas, "Effect of nano-metakaolin addition on the hydration characteristics of fly ash blended cement mortar", Journal of thermal analysis and calorimetry, 116 (2), pp. 845-852, 2013.

[21] M. Soneby, K. H. Khayat, "Testing abrasion resistance of high-strength concrete", Cement concrete and aggregates, vol. 23, no. 1, pp. 34-43, 2001.

[22] Semsi Yazici, Gozde Inan Sezer, "Abrasion resistance estimation of high strength concrete", Journal of engineering sciences, vol. 6(3), pp. 136-148, 2015.

[23] Benjamin D. Scott, Md. Safiuddin, "Abrasion resistance of concrete - design construction and case study", Concrete research letters, vol. 13, no. 1, pp. 1-6, 2001.

[24] N.N. Kalinovskaia, D.S. Kotov, E.A. Ivanova, "Dolgovechnost' betona. Analiz prichin i sposoby snizheniya usadochnyh deformacij modificirovannogo betona", Tehnologii betonov, no. 11-12, pp. 14-17, 2017.

[25] J.J. Brooks, M.A. Megat Johari, H. Abbas, "Effect of metakaolin on creep and shrinkage of concrete", Cement \& concrete composites, pp. 495-502, 2001.

[26] N. Gowripalan, "Autogenous shrinkage of concrete at early ages", $25^{\text {th }}$ Australian conference on mechanics of structures and materials, 2018, pp. 1-8. 
[27] I.S. Karimov, "Mehanizm usadochnyh deformacij betona i faktory, vliyayuschie na nih", Tehnologii betonov, no. 05-06, pp. 22-24. 2010.

[28] Erhan Guneyisi, Mehmet Gesoglu, Kasim Mermerdas. "Improving strength, drying shrinkage, and pore structure of concrete using metakaolin", Materials and structures, 41 (5), pp. 937-949, 2008.

[29] D.O. Kazantsev, A.A. Kirsanova, "Perspektivy primeneniya metakaolina dlya snizheniya usadki cementnogo kamnya", Vestnik YUUrGU «Stroitel'stvo i arhitektura», T. 20, no. 2, pp. 49-53, 2020.

\title{
ВПЛИВ МЕТАКАОЛІНУ НА МОДИФІКОВАНИЙ ПОЛІКАРБОКСИЛАТНОЮ ДОБАВКОЮ БЕТОН ДЛЯ РЕМОНТУ ЖОРСТКИХ ПОКРИТТІВ ДОРІГ
}

\author{
${ }^{1}$ Крижановський В.О., інженер, \\ vitolloscience@gmail.com, ORCID: 0000-0003-1332-1922 \\ ${ }^{1}$ Кровяков С.О., д.т.н., доцент, \\ skrovyakov@ukr.net, ORCID 0000-0002-0800-0123 \\ ${ }^{1}$ Заволока М.В., к.т.н., професор, \\ mvzavoloka@ukr.net, ORCID: 0000-0002-2080-1230 \\ ${ }^{1}$ Одеська державна академій будівництва та архітектури \\ вул. Дідріхсона, 4, м. Одеса, 65029, Україна
}

Анотація. Досліджено вплив часткової заміни цементу високоактивним метакаоліном на міцність, морозостійкість, усадку і зносостійкість модифікованих полікарбоксилатною добавкою MasterGlenium SKY 608 бетонів. Для приготування бетонів використовувався цемент ПЦ II/A-Ш-500 (CEM II/A-S 42,5) з частковою заміною метакаоліном: 15 кг (3.75\%) i 30 кг (7.5\%). Кількість суперпластифікатора у всіх досліджуваних композиціях складала 1,2\% від маси цементу. Марка рухливості бетонних сумішей Р2.

Встановлено, що 3 підвищенням кількості метакаоліну В/Ц сумішей незначно підвищувалося. При цьому рання міцність (у віці 2-х діб) на стиск і розтяг при згині складу без метакаоліну була вище аналогічних показників з частковою заміною цементу на активну мінеральну добавку. Варто відзначити позитивний вплив підвищення кількості метакаоліну на ранню міцність, тому що склад з більшою кількістю метакаоліну (30 кг) мав показники міцності вище на 2 добу твердіння на відміну від складу з 15 кг метакаоліну.

За рахунок використання добавки MasterGlenium SKY 608 на основі портландцементу ПЦ II/А-Ш-500 був отриманий високоміцний бетон для ремонту жорстких дорожніх покриттів з міцністю 87,5 МПа, що приблизно відповідає класу С50/60. Заміна 15 кг цементу на метакаолін дозволила отримати бетон того ж класу С50/60 з міцністю 85,2 МПа, а при заміні 30 кг цементу був отриманий бетон класу С45/55 з міцністю 78,4 МПа. Середня густина досліджених бетонів становила від 2480 до $2580 \mathrm{\kappa г} / \mathrm{m}^{3}$.

Необхідно відзначити високу морозостійкість всіх отриманих бетонів. Їх марка по морозостійкості досягла F200 (при оцінці за методикою для дорожніх бетонів), що еквівалентно марці F600 для конструкційних бетонів. Показники зносостійкості були в низьких межах $\left(0,30-0,31 \quad \Gamma / \mathrm{cm}^{2}\right)$, усадка до $0,28 \mathrm{mм} / \mathrm{M}$ що в сукупності 3 високою морозостійкістю робить позитивний вплив на довговічність ремонтних складів жорстких дорожніх одягів.

Ключові слова: жорсткі дорожні покриття, ремонт, рання міцність, усадка, морозостійкість, зносостійкість, метакаолін, суперпластифікатор. 


\title{
ВЛИЯНИЕ МЕТАКАОЛИНА НА МОДИФИЦИРОВАННЫЙ \\ ПОЛИКАРБОКСИЛАТНОЙ ДОБАВКОЙ БЕТОН ДЛЯ РЕМОНТА ЖЕСТКИХ ПОКРЫТИЙ ДОРОГ
}

\author{
${ }^{1}$ Крыжановский В.А., инженер, \\ vitolloscience@gmail.com, ORCID: 0000-0003-1332-1922 \\ ${ }^{1}$ Кровяков С.А., Д.Т.н., доцент, \\ skrovyakov@ukr.net, ORCID 0000-0002-0800-0123 \\ 1заволока М.В., к.т.н., профессор, \\ mvzavoloka@ukr.net, ORCID: 0000-0002-2080-1230 \\ ${ }^{1}$ Одесская государственная академия строительства и архитектуры \\ ул. Дидрихсона, 4, г. Одесса, 65029, Украина
}

\begin{abstract}
Аннотация. Исследовано влияние частичной замены цемента высокоактивным метакаолином на прочность, морозостойкость, усадку и износостойкость модифицированных поликарбоксилатной добавкой MasterGlenium SKY 608 бетонов. Для приготовления бетонов использовался цемент ПЦ II/A-Ш-500 (CEM II/A-S 42,5) с частичной заменой метакаолином: 15 кг (3.75\%) и 30 кг (7.5\%). Количество суперпластификатора во всех исследуемых композициях составило 1,2\% от массы цемента. Марка подвижности бетонных смесей Р2.

Установлено, что с повышением количества метакаолина В/Ц смесей незначительно повышалось. При этом ранняя прочность (в возрасте 2 х суток) на сжатие и растяжение при изгибе состава без метакаолина была выше аналогичных показателей с частичной заменой цемента на активную минеральную добавку. Стоит отметить позитивное влияние повышения количества метакаолина на раннюю прочность, т.к. состав с большим количеством метакаолина (30 кг) имел прочностные характеристики выше на 2е сутки твердения в отличие от состава с 15 кг метакаолина.

За счет использования добавки MasterGlenium SKY 608 на основе портландцемента ПЦ II/A-Ш-500 был получен высокопрочный бетон для ремонта жестких дорожных покрытий с прочностью 87,5 МПа, что примерно соответствует классу С50/60. Замена 15 кг цемента на метакаолин позволила получить бетон того же класса С 50/60 с прочностью 85,2 МПа, а при замене 30 кг цемента был получен бетон класса C45/55 с прочностью 78,4 МПа. Средняя плотность исследованных бетонов составляла от 2480 до $2580 \mathrm{\kappa г} / \mathrm{m}^{3}$.

Необходимо отметить высокую морозостойкость всех полученных бетонов. Их марка по морозостойкости достигла F200 (при оценке по методике для дорожных бетонов), что эквивалентно марке F600 для конструкционных бетонов. Показатели износостойкости были

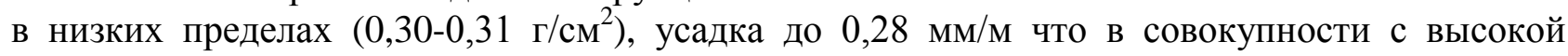
морозостойкостью оказывает положительное влияние на долговечность ремонтных составов жестких дорожных одежд.
\end{abstract}

Ключевые слова: жесткие дорожные покрытия, ремонт, ранняя прочность, усадка, морозостойкость, износостойкость, метакаолин, суперпластификатор.

Стаття надійшла до редакції 20.11.2020

Bulletin of Odessa State Academy of Civil Engineering and Architecture, 2021, no. 82, page 90-97 